\title{
KUALITAS PROSES DAN HASIL BELAJAR BIOLOGI MELALUI PENGAJARAN DENGAN MODEL PEMBELAJARAN KOOPERATIF TIPE JIGSAW PADA MADRASAH ALIYAH NEGERI 2 MADIUN
}

\author{
Sri Utami \\ IKIP PGRI MADIUN \\ Sriutami31@yahoo.co.id.
}

Pendidikan saat ini dihadapkan pada tuntutan yang semakin meningkat, baik ragam, lebihlebih kualitasnya, termasuk pendidikan pada MAN 2 Madiun. Di sisi lain, berdasarkan hasil evaluasi dengan kurikulum 2007, diketahui bahwa siswa belum mencapai kemampuan optimalnya. Siswa hanya tahu banyak fakta tetapi kurang mampu memanfaatkannya, oleh sebab itu sistem pendidikan saat ini dan di masa depan harus dikembangkan agar lebih responsif terhadap tuntutan masyarakat dan tantangan yang akan dihadapi.

Penelitian pengembangan ini dilakukan dengan tujuan untuk; (1) Mengembangkan perangkat pembelajaran biologi SMU/MA yang bercirikan model pembelajaran kooperatif tipe jigsaw, dan (2) Mengetahui kualitas proses dan hasil belajar biologi melalui penerapan perangkat pembelajaran dengan model pembelajaran kooperatif tipe jigsaw.

Penelitian dilakukan pada bulan Februari sampai Juni 2010 dalam dua tahap, yaitu (1) Tahap Pengembangan Perangkat, dan (2) Tahap Pembelajaran Nyata. Perangkat pembelajaran yang dikembangkan adalah Materi Ajar, Rencana Pembelajaran, Lembar Kegiatan Siswa, dan Instrumen Tes Hasil Belajar.

Hasil penelitian menunjukkan; (1) Guru mampu melakukan keseluruhan aspek pembelajaran dengan kategori baik, (2) Aktivitas guru yang dominan adalah mengelola KBM sesuai kaidah pembelajaran kooperatif, dan melatihkan siswa keterampilan kooperatif, (3) Aktivitas siswa yang dominan adalah membaca Materi Ajar, LKS, dan menulis yang relevan, (4) Keterampilan kooperatif siswa yang dominan adalah mengambil giliran dan berbagi tugas, (5) Siswa menyatakan senang dan baru terhadap perangkat dan model pembelajaran, (6) Guru menganggap perangkat pembelajaran cukup membantu dan bermanfaat, dan (7) KBM yang menerapkan perangkat dan model pembelajaran kooperatif tipe jigsaw dapat menuntaskan belajar siswa.

\section{Kata Kunci: Kualitas proses dan hasil belajar, Jigsaw,}

\section{PENDAHULUAN}

Madrasah Aliyah(MA) merupakan lembaga pendidikan Islam setingkat SMU yang memberi pengajaran agama Islam. Menurut Muhtarom (2002), MA bertujuan tidak semata-mata memperkaya pikiran siswa dengan teks-teks dan penjelasanpenjelasan yang Islami, tetapi juga untuk meninggikan moral, melatih dan mempertinggi semangat, menghargai nilainilai spiritual dan kemanusiaan. MA mengajarkan sikap dan tingkah-laku yang jujur dan bermoral, serta menyiapkan murid untuk hidup sederhana dan bersih hati.

Madrasah Aliyah dihadapkan pada dualisme tuntutan. Di satu sisi, lulusan harus dipersiapkan dengan kemampuan akademis yang memadai agar bisa melanjutkan pendidikan ke tingkat yang lebih tinggi, di sisi lain, lulusan dituntut harus mempunyai moralitas yang tinggi atau yang lebih dikenal dengan berakhlak mulia sesuai dengan tuntutan Qur'an dan sunnah Rasulullah agar nantinya setelah kembali ke 
masyarakat dapat menjadi contoh dan teladan yang baik bagi masyarakat. Bahkan jauh dari itu, lulusan diharapkan bisa menjadi seorang dai yang akan menyebarkan nilai-nilai Ilahiyah kepada seluruh lapisan masyarakat.

Kemampuan akademis yang diharapkan adalah sama dengan yang dituntut pada sekolah menengah umum, meliputi kemampuan bidang umum antara lain biologi, fisika, kimia, matematika dan sebagainya. Ditambah dengan kemampuan akademis bidang agama Islam antara lain Aqidah Akhlaq, Fiqih, Ilmu Hadis, dan sebagainya. Tuntutan akademis bidang agama Islam dan kepondokan inilah yang membedakan pendidikan pada Madrasah Aliyah dengan bidang akademis pada sekolah menengah umum (SMU). Sedangkan tuntutan moralitas atau akhlak mulia antara lain; sikap menghormati dan menghargai sesama manusia, menghargai adanya perbedaan antar pribadi dalam segala aspek, demokratis, dan sikap-sikap positif lainnya. Dengan demikian, upaya inovasi pengajaran yang mengarah kepada pencapaian kedua tujuan tersebut mutlak diperlukan pada Madrasah Aliyah.

Ada beberapa alasan mendasar mengapa inovasi pendidikan Madrasah Aliyah terasa urgen dan mendesak untuk dilakukan. Dalam kaitan ini Sudirman Tebba, seorang peneliti pesantren yang dikutip dalam Magfurin (2002) mengemukakan alasannya, yaitu (a) Madrasah Aliyah sebagai lembaga pendidikan, dakwah, dan sosial dirasakan oleh banyak pihak memiliki potensi besar untuk memberikan sumbangan pemikiran dalam bidang pendidikan dan pengembangan masyarakat, (b) Jumlah pesantren potensial terbukti pula melaksanakan usaha kreatif yang bersifat rintisan. Upaya inovasi pembelajaran dalam lingkup madrasah perlu dikembangkan sambil terus melakukan upaya pembenahan terhadap masalah utama yang dihadapi pesantren, baik yang bersifat internal maupun yang eksternal.

Berdasarkan pengamatan penulis Pola pengajaran yang dilakukan pada madarasah Aliyah Negeri 2 Madiun (MAN 2 Madiun) telah melakukan perbaikan-perbaikan mengarah pada terciptanya dualisme tuntutan pendidikan di MA. Pengajaran bidang-bidang akademis digerakan untuk menggunakan model-model inovatif yang diharapkan membuahkan kemampuan kognitif, afektif, dan psikomotorik. Pola pengajaran yang ada menuntut siswa berakhlak mulia atau bermoralitas tinggi yaitu melalui penanaman pemahaman (kognitif), afektif (sikap), psikomotorik. Usaha pencapaian tiga ranah kompetensi diatas juga dilakukan melalui pengkajian AlQuran dan hadis pada mata pelajaran aqidah akhlak, fiqih, ilmu hadis, dan sebagainya.

Jika dianalisis lebih mendalam, bahwa hampir semua sikap positif yang terkandung dalam istilah "akhlak mulia" atau "bermoral" adalah sama halnya dengan keterampilan. Keterampilan tersebut agar bisa mendarah daging pada peserta didik harus dilatihkan secara terus-menerus dan terintegrasi pada semua hidang studi. Jadi tidak cukup dengan pemahaman dan pengkajian saja, karena hal itu akan membuahkan hasil yang sifatnya kognitif bagi siswa .

Pembelajaran IPA khususnya diarahkan pada kegiatan-kegiatan yang mendorong siswa belajar secara aktif, baik fisik, mental-intelektual, maupun sosial (kelompok) untuk memahami konsepkonsep IPA, khususnya biologi. Pola pengembangan pembelajaran biologi di kelas diharapkan menggambarkan adanya keterlibatan aktif seluruh siswa dalam kegiatan pembelajaran, menemukan sendiri pengetahuan melalui interaksi dengan lingkungan. Intinya pembelajaran biologi yang dikehendaki kurikulum SMU/MA 
2007 adalah pembelajaran yang tidak mengabaikan hakikat IPA dan mencerminkan sifat IPA sebagai ilmu pengetahuan alam. Hakikat IPA yang dimaksud adalah mencakup produk ilmiah, proses ilmiah, dan sikap ilmiah melalui pendekatan keterampilan proses yaitu pendekatan dalam proses belajar mengajar yang menekankan pembentukan keterampilan memperoleh pengetahuan dan mengkomunikasikannya.

Berdasarkan hasil pengamatan penulis, bahwa dalam kegiatan belajar mengajar biologi yang ada pada MAN 2 Madiun selama ini telah menerapkan pembelajaran berkelompok untuk menyampaikan konsepkonsep biologi. Beberapa tugas yang harus dikerjakan siswa secara kelompok seperti mengerjakan praktikum di laboratorium, tugas mengerjakan soal-soal latihan, tugas membaca, dan masih banyak lagi tugas lainnya. Tetapi kalau dicermati, kegiatan kelompok tersebut bukan pembelajaran kooperatif. Tujuan dari kerja kelompok hanya menyelesaikan tugas. Kegiatan belajar mengajar tersebut biasanya hanya didominasi oleh siswa yang pandai, sementara siswa yang kemampuannya rendah kurang berperan dalam mengerjakan tugas kelompok. Di samping itu siswa kurang dilatihkan untuk bekerja sama, berkomunikasi, dan menghargai pendapat orang lain. Akibat cara kerja kelompok seperti ini menyebabkan siswa yang kemampuannya kurang memperoleh hasil belajar biologi yang tetap rendah dan adanya kesenjangan yang terlalu jauh antara hasil belajar siswa yang pandai dengan hasil belajar siswa yang kurang pandai.

Pada mata pelajaran biologi SMU/MA kelas $\mathrm{X}$ semester 2, terdapat pokok bahasan "Aksi Interaksi". Pokok bahasan Aksi Interaksi membahas tentang hubungan timbal balik antar komponen biotik dengan biotik, dan hubungan komponen biotik dan abiotik dalam ekosistem. Pokok Bahasan
Aksi Interaksi terdiri dari tiga subpokok bahasan, yaitu subpokok bahasan pola-pola aksi interaksi, subpokok bahasan suksesi, dan subpokok bahasan macam-macam ekosistem. Setiap subpokok bahasan bukan merupakan materi persyaratan untuk materi yang lain. Berdasarkan tuntutan GBPP Bidang Studi Biologi Kurikulum 2007, pembelajaran yang dianjurkan adalah pembelajaran dengan pendekatan kelompok yang berbasis pada keterampilan proses dan aktivitas siswa yang berorientasi pemecahan masalah berdasarkan pengamatan dan diskusi dengan menggunakan metode ilmiah untuk memahami prinsip dan pola interaksi dalam ekosistem. Dengan demikian, pembelajaran yang mungkin dilakukan adalah pembelajaran yang berorientasi pemecahan masalah berdasarkan hasil pengamatan dan diskusi kelompok yang identik dengan model pembelajaran kooperatif tipe jigsaw.

Pengajaran pokok bahasan Aksi Interaksi pada MAN 2 Madiun biasanya dilakukan dengan metode diskusi. Untuk mengarahkan diskusi guru memberikan sejumlah pertanyaan kepada kelompok yang memuat hampir seluruh isi materi yang ada dalam konsep tersebut. Hasil evaluasi pengajaran konsep ini juga tetap menunjukkan adanya perbedaan yang terlalu jauh antara hasil belajar siswa yang pandai dan hasil belajar siswa yang kurang pandai.

Dewasa ini telah banyak digunakan model pembelajaran kooperatif. Bahkan pembelajaran kooperatif ini merupakan suatu model pembelajaran yang banyak dikembangkan. Beberapa ahli menyatakan bahwa model pembelajaran kooperatif tidak hanya unggul dalam membantu siswa untuk memahami konsep, tetapi juga membantu siswa menumbuhkan kemampuan kerja sama, berpikir kritis dan mengembangkan sikap sosial siswa. Di samping itu, keterampilan kooperatif menjadi semakin penting untuk keberhasilan dalam 
menghadapi tuntutan lapangan kerja yang sekarang ini berorientasi pada kerja sama dalam tim. Karena pentingnya interaksi dalam tim, maka penerapan strategi pembelajaran kooperatif dalam pendidikan menjadi lebih penting.

Tipe pembelajaran kooperatif ada bermacam-macam, salah satunya adalah pembelajaran kooperatif tipe jigsaw. Lie A. (1994) menyatakan bahwa, jigsaw merupakan salah satu tipe metode pembelajaran kooperatif yang fleksibel. Sejumlah riset telah banyak dilakukan berkaitan dengan pembelajaran kooperatif dengan dasar jigsaw. Riset tersebut secara konsisten menunjukkan bahwa siswa yang terlibat dalam pembelajaran semacam itu memperoleh prestasi yang lebih baik, dan mempunyai sikap yang lebih baik pula terhadap pembelajaran.

Dari uraian di atas, perlu untuk melakukan penelitian dengan mengembangkan perangkat pembelajaran yang bercirikan model pembelajaran kooperatif tipe jigsaw sebagai salah satu alternatif dalam mengatasi permasalahan pembelajaran biologi pada Madrasah Aliyah Negeri 2 Madiun. Penelitian ini berjudul Meningkatkan kualitas proses dan hasil belajar biologi siswa MAN 2 Madiun melalui penerapan model pembelajaran kooperatif tipe Jigsaw.

\section{METODE PENELITIAN}

Penelitian ini merupakan penelitian pengembangan, karena mengembangkan perangkat pembelajaran biologi kelas X MA pokok bahasan Aksi Interaksi bercirikan model pembelajaran kooperatif tipe jigsaw. Perangkat pembelajaran yang dikembangkan meliputi Materi Ajar, Rencana Pembelajaran, Lembar Kegiatan Siswa, dan Buku Panduan Guru. Subjek Penelitian adalah siswa kelas X-A Madrasah Aliyah Negeri 2 Madiun Jawa Timur. Penelitian ini dilaksanakan pada Februari sampai 18 Juni 2010 .
Variabel-variabel penelitian dijelaskan dengan definisi operasional sebagai berikut.

a. Kemampuan guru mengelola pembelajaran adalah skor yang diperoleh guru dalam melaksanakan PBM yang meliputi persiapan, pendahuluan, kegiatan inti, penutup, pengelolaan waktu, dan pengelolaan kelas yang diukur dengan instrumen lembar observasi kemampuan guru (Instrumen 01).

b. Aktivitas siswa dalam pembelajaran kooperatif tipe jigsaw adalah banyaknya aktivitas yang dilakukan siswa selama proses belajar mengajar dan diamati dengan instrumen lembar observasi aktivitas siswa (Instrumen 02). Aktivitas siswa yang dimaksud meliputi mendengarkan atau memperhatikan penjelasan guru atau teman, membaca LKS, Materi Ajar dan menulis yang relevan, mengerjakan LKS pada kelompok ahli, berlatih melakukan keterampilan kooperatif, dan mempresentasikan hasil kerja kelompok.

c. Aktivitas guru dalam mengelola pembelajaran kooperatif tipe jigsaw adalah sejumlah keterlibatan guru selama proses belajar mengajar yang diamati dengan instrumen lembar observasi aktivitas guru dalam mengelola pembelajaran kooperatif tipe jigsaw (Instrumen 02). Aktivitas guru yang dimaksud meliputi menyampaikan TPK/memotivasi siswa, menyajikan informasi tentang materi pelajaran, mendorong/melatihkan keterampilan kooperatif pada siswa, dan mengelola KBM sesuai kaidah pembelajaran kooperatif tipe jigsaw.

d. Keterampilan kooperatif siswa sejumlah aktivitas siswa yang bercirikan kooperatif yaitu, menghargai kontribusi, mengambil giliran dan berbagi tugas, mengajukan pertanyaan, mendengarkan dengan aktif, dan memeriksa ketepatan 
yang diamati dengan instrumen lembar observasi keterampilan kooperatif siswa (Instrumen 03).

e. Respon siswa adalah pendapat/penilaian siswa terhadap pelaksanaan KBM. Respon siswa ini diukur dengan cara mengisi angket setelah KBM dengan instrumen angket respon siswa (Instrumen 04). Komponen yang dimaksud meliputi: materi pelajaran; buku ajar siswa, LKS, media belajarnya, suasana kelas, dan cara guru mengajar. Dalam hal ini siswa berpendapat apakah siswa merasa senang atau tidak dalam KBM, merupakan hal baru atau tidak.

f. Kesan guru adalah tanggapan atau penilaian guru terhadap penerapan perangkat pembelajaran dan model pembelajaran kooperatif tipe jigsaw dan diukur dengan Instrumen Kesan Guru. (Instrumen 05).

g. Hasil belajar siswa adalah skor yang diperoleh siswa dari tes hasil belajar berupa tes hasil belajar produk dan tes hasil belajar proses yang diukur dengan Instrumen Tes Hasil Belajar (Instrumen 06 dan Instrumen 07).

\section{Prosedur Penelitian}

Penelitian dilaksanakan dalam dua tahap. Tahap pertama adalah tahap pengembangan perangkat, dan tahap kedua adalah tahap pembelajaran nyata.

\section{Tahap Pengembangan Perangkat}

Pengembangan perangkat pembelajaran dalam penelitian ini, mengikuti model pengembangan Kemp et al. (1994). Model Kemp merupakan suatu lingkaran yang kontinum. Setiap unsur pengembangan berhubungan secara langsung dengan aktivitas revisi. Pengembangan perangkat dapat dimulai dari unsur yang manapun di dalam siklus itu. Sesuai dengan kurikulum SMU/MA 1994 yang berorientasi pada tujuan, pengembangan dalam penelitian ini dimulai dari tujuan dan berakhir pada evaluasi. Dalam penelitian ini, peneliti mengadopsi kesembilan unsur yang terdapat pada model pemgembangan Kemp et al. (1994), yaitu (1) Instructional Problems, (2) Learner Characteristics, (3) Task Analysis, (4) Instructional Objectives, (5) Content Sequencing, (6) Instructional Strategies, (7) Instructional Delivery, (8) Evaluation Instrumens, dan (9) Instructional Resources.

\section{Ujicoba II (Pembelajaran Nyata)}

Sebagai tahap kedua dari penelitian ini adalah, tahap Ujicoba II (pembelajaran nyata) setelah dilakukan pengembangan perangkat pembelajaran dan diujicobakan pada Ujicoba I.

Tahap ini dilakukan dengan tujuan; menerapkan perangkat pembelajaran pada pembelajaran nyata setelah direvisi berdasarkan hasil Ujicoba I, dan mengetahui bagaimana kualitas proses belajar mengajar dan kualitas hasil belajar siswa dengan menggunakan perangkat pembelajaran yang telah dikembangkan. Ujicoba II telah dilaksanakan dari tanggal 2 sampai 18 Juni 2010 pada Madrasah Aliyah Negeri 2 Madiun.

Pelaksanaan Ujicoba I dan Ujicoba II, meliputi; uji awal (pretest), kegiatan belajar mengajar (KBM), dan uji akhir (posttest).

Selama kegiatan belajar mengajar dilakukan pengamatan terhadap:

a) Kemampuan guru dalam mengelola pembelajaran kooperatif tipe jigsaw.

b) Aktivitas siswa.

c) Aktivitas guru.

d) Keterampilan kooperatif siswa.

Pengamatan dilakukan oleh dua orang pengamat. Pengamatan berorientasi pada instrumen yang telah disusun oleh peneliti. Sebelum melakukan pengamatan, para pengamat akan diberikan penjelasan dan latihan oleh peneliti perihal kegiatan pengamatan selama Ujicoba.

Kegiatan Ujicoba I dan Ujicoba II menggunakan rancangan One-Group 
Pretest-Posttest Design, karena dilakukan pada satu kelompok, tanpa kelompok pembanding. Rancangan penelitian, digambarkan sebagai berikut.

\begin{tabular}{|lll|}
\hline $\mathrm{O}_{1}$ & $\mathrm{X}$ & $\mathrm{O}_{2}$ \\
\hline
\end{tabular}

(Tuckman, 1978)

Keterangan:

$$
\begin{aligned}
\mathrm{O}_{1}= & \mathrm{Uji} \text { awal } \\
\mathrm{O}_{2}= & \mathrm{Uji} \text { akhir } \\
\mathrm{X}= & \text { Pembelajaran dengan } \\
& \text { perangkat pembelajaran } \\
& \text { dan model } \\
& \text { pembelajaran kooperatif } \\
& \text { tipe Jigsaw oleh Peneliti } \\
& \text { dan Guru Mitra. }
\end{aligned}
$$

\section{Instrumen Penelitian}

Instrumen yang digunakan dalam penelitian ini dikelompokkan menjadi 3 macam yaitu; (1) Instrumen tes hasil belajar, (2) lembar pengamatan, dan (3) angket respon siswa dan kesan guru.

\section{Tes Hasil Belajar (THB)}

Instrumen tes hasil belajar digunakan untuk menilai kualitas hasil belajar siswa setelah selesai pembelajaran tiga rencana pembelajaran (RP). THB pokok bahasan "Aksi Interaksi" berbentuk pilihan ganda dan essai. THB dikembangkan oleh peneliti dengan mengacu pada tujuan pembelajaran khusus yang telah dibuat.

\section{Lembar Pengamatan, antara lain:}

a. Lembar Pengamatan Pengelolaan Pembelajaran Model Kooperatif Tipe Jigsaw (Instrumen 01)

b. Lembar pengamatan Aktivitas Guru dan Siswa (Instrumen 02)

c. Lembar Pengamatan Keterampilan Kooperatif (Instrumen 03)

\section{Angket Respon Siswa dan Kesan Guru (Instrumen 04 dan 05)}

Dalam angket respon siswa terhadap KBM, siswa diminta mengemukakan pendapatnya tentang kekinian (baru/tidak baru) dan kesukaan (senang/tidak senang) terhadap perangkat pembelajaran dan kegiatan pembelajaran yang berorientasi pada model pembelajaran kooperatif tipe jigsaw. Sedangkan angket kesan guru terhadap perangkat pembelajaran dan model pembelajaran kooperatif tipe jigsaw, guru diminta untuk memberikan penilaian terhadap perangkat pembelajaran yang telah dikembangkan oleh peneliti dan model pembelajaran yang diterapkan, apakah sangat membantu atau tidak, dan bagaimana kelebihan dan kekurangan penerapan perangkat pembelajaran dengan model pembelajaran kooperatif tipe jigsaw, serta guru memberikan komentar tentang kemudahan dan hambatan selama penerapan model pembelajaran tersebut. Instrumen ini dikembangkan dengan mengacu pada Instrumen dalam Nur (1999b).

\section{Teknik Analisis Data}

Analisis data dibedakan atas 2 macam, yaitu analisis untuk menghitung reliabilitas dan validitas instrumen, dan analisis data untuk menjawab pertanyaan penelitian.

\section{Analisis data untuk menghitung} reliabilitas dan validitas instrumen

Sebelum digunakan untuk menilai kualitas proses dan kualitas hasil belajar siswa pada Pembelajaran Nyata (Ujicoba II), instrumen pengamatan dan instrumen THB yang akan dipakai, terlebih dahulu dianalisis reliabilitas dan validitasnya. Reliabilitas dan validitas instrumen dihitung berdasarkan data hasil Ujicoba I.

Reliabel instrumen pengamatan akan dihitung dengan teknik interobserver agreement. Dua orang pengamat pada ujicoba menggunakan instrumen yang sama untuk mengamati variabel yang sama. Kedua pengamat tersebut diminta untuk menilai sesuai dengan instrumen pengamatan yang diujicobakan. Rumus yang akan digunakan untuk menghitung reliabilitas adalah: 


\author{
Percent agreement $(\mathrm{R})=100$ \\ $\left[1-\frac{A-B}{A+B}\right]$ (Borich, 1994). \\ Keterangan : \\ $\mathrm{A}=$ Frekuensi aspek tingkah- \\ laku yang teramati oleh pengamat \\ dengan memberikan frekuensi \\ tinggi. \\ $\mathrm{B}=$ Frekuensi aspek tingkah- \\ laku yang teramati oleh pengamat \\ lain dengan memberikan frekuensi \\ rendah.
}

Agar diperoleh reliabilitas yang tinggi dilakukan hal-hal sebagai berikut.

(1) Pengamatan dilakukan oleh dua pengamat tentang tingkah laku yang sama pada saat yang sama.

(2) Mendefinisikan dengan jelas setiap tingkah laku yang diamati.

(3) Memberi latihan pada pengamat.

Validitas butir tes akan diperoleh dengan menghitung sensitivitas butir dari setiap butir soal. Rumus yang akan digunakan adalah (Gronlund, 1982):

$$
\text { Sensitivitas }(\mathrm{S})=\frac{R a-R b}{T}
$$

$\mathrm{S}=$ indeks sensitivitas butir soal

$\mathrm{Ra}=$ jumlah siswa yang menjawab benar pada tes akhir

$\mathrm{Rb}=$ jumlah siswa yang menjawab benar pada tes awal

$\mathrm{T}=$ jumlah siswa yang mengikuti tes

Indeks butir yang efektif terdapat di antara 0,00 dan 1,00 dan nilai positif yang lebih besar menyatakan butir soal yang lebih besar kepekaannya terhadap efek-efek pembelajaran (Gronlund, 1982). Butir soal yang mempunyai sensitivitsas $\geq 0.40$ maka butir soal tersebut peka terhadap efek-efek pembelajaran (Arikunto S., 1991). Sehingga dalam penelitian ini, butir soal yang dianggap layak digunakan untuk menilai kualitas hasil belajar siswa pada Ujicoba II adalah butir soal yang mempunyai sensitivitas $\geq 0.40$ dari hasil Ujicoba I.
Jika suatu butir soal dijawab benar oleh semua siswa sebelum dan sesudah pembelajaran, maka butir soal tersebut tidak mengukur efek-efek pembelajaran. Sebaliknya, jika suatu butir soal tidak dapat dijawab benar oleh semua siswa sebelum dan sesudah pembelajaran, maka soal itu juga tidak memenuhi fungsinya. Untuk mengetahui sensitivitas butir soal, uji awal dan uji akhir yang sama harus diberikan kepada siswa. Butir soal yang sensitif dijawab oleh lebih banyak siswa setelah pembelajaran berlangsung. Nilai positif yang semakin besar menunjukkan bahwa kepekaan butir soal terhadap efek-efek pembelajaran semakin besar.

\section{Analisis data untuk menjawab pertanyaan penelitian}

Analisis data untuk menjawab pertanyaan penelitian dilakukan dengan menggunakan statistik deskriptif, berupa rata-rata, atau persentase, yang akan diuraikan sebagai berikut.

\section{a. Analisis data pengelolaan pembelajaran}

Analisis data pengelolaan pembelajaran digunakan untuk menjawab pertanyaan "Bagaimana kemampuan guru dalam mengelola pembelajaran yang berorientasi model pembelajaran kooperatif tipe jigsaw ?"

Untuk menganalisis hasil penilaian yang diberikan oleh pengamat terhadap kemampuan guru dalam mengelola pembelajaran kooperatif tipe jigsaw akan digunakan ketentuan (Budiningarti, 1998): 0.00 - 1.99 tidak baik; 2.00 - 2.99 kurang baik; 3.00 - 3.49; cukup baik; 3.50 - 4.00 baik

b. Analisis data pengamatan aktivitas guru, aktivitas siswa, dan keterampilan kooperatif siswa

Analisis ini digunakan untuk menjawab pertanyaan penelitian "Bagaimana aktivitas guru dan aktivitas siswa selama pembelajaran ?", dan 
"Bagaimana keterampilan kooperatif siswa dalam pembelajaran kooperatif tipe jigsaw ?'.Data hasil pengamatan aktivitas guru, aktivitas siswa, dan keterampilan kooperatif siswa selama KBM berlangsung dianalisis dengan menggunakan persentase $(\%)$, yakni banyaknya frekuensi aktivitas dibagi dengan seluruh frekuensi aktivitas, dikali $100 \%$.

\section{c. Analisis data respon siswa terhadap perangkat pembelajaran dan KBM}

Anlaisis data respon siswa digunakan untuk menjawab pertanyaan penelitian "Bagaimana respon siswa terhadap penerapan perangkat dan model pembelajaran yang berorientasi model pembelajaran kooperatif tipe jigsaw?"

Data respon siswa dianalisis dengan persentase, yakni jumlah siswa yang memberikan respon sama dibagi dengan jumlah siswa seluruhnya, dikali $100 \%$.

\section{d. Analisis data kesan guru terhadap perangkat pembelajaran dan KBM}

Anlaisis data kesan guru digunakan untuk menjawab pertanyaan penelitian "Bagaimana kesan guru terhadap penerapan perangkat dan model pembelajaran kooperatif tipe jigsaw?"

Data yang berupa jawaban guru terhadap sejumlah butir pertanyaan pada angket kesan guru, langsung dideskripsikan apa adanya untuk menggambarkan kesan atau penilaian guru terhadap perangkat pembelajaran yang telah dikembangkan dan penerapan perangkat dan model pembelajaran kooperatif tipe jigsaw yang telah dilakukan selama kegiatan Ujicoba.

\section{e. Analisis data hasil Tes Hasil Belajar}

Anlaisis data hasil belajar siswa digunakan untuk menjawab pertanyaan penelitian "Bagaimana hasil belajar siswa berupa produk dan proses pada pembelajaran dengan model pembelajaran kooperatif tipe jigsaw ?"

Hasil belajar siswa ditentukan berdasarkan penilaian acuan patokan. Skor yang diperoleh siswa melalui THB akan digunakan untuk menentukan ketuntasan individual dan ketuntasan klasikal siswa terhdap TPK yang telah ditetapkan. Ketuntasan individual atau ketuntasan per siswa ditentukan dengan rumus:

$$
\mathrm{p}=\frac{\mathrm{Si}}{\mathrm{Sm}} \times 100 \%
$$

(Dikembangkan dari Depdikbud, 1995).

Keterangan: $\mathrm{p}=$ Persen ketuntasan belajar per siswa (proporsi siswa)

$\mathrm{Si}=$ Jumlah skor yang dicapai siswa terhadap seluruh butir soal

$\mathrm{St}=$ Jumlah skor total seluruh butir soal Sebagai standar ketuntasan belajar digunakan patokan yang ditetapkan Depdikbud (1995) dalam Kurikulum 1994, yaitu siswa dikatakan tuntas belajarnya jika proporsi jawaban benar siswa, atau persen ketuntasan belajarnya $\geq 65 \%$. Suatu kelas dikatakan tuntas belajarnya jika di kelas tersebut terdapat $85 \%$ siswa telah mencapai ketuntasan individual.

Hasil analisis ketuntasan individual dan ketuntasan klasikal selanjutnya akan digunakan untuk mendeskripsikan kualitas hasil belajar siswa Pokok Bahasan "Aksi Interaksi" melalui pengajaran dengan Model Pembelajaran Kooperatif Tipe Jigsaw sesuai dengan tujuan penelitian ini.

\section{HASIL DAN PEMBAHASAN}

\section{Hasil Pengembangan Perangkat}

\section{Pembelajaran}

1. Materi Ajar Pokok Bahasan Aksi Interaksi

Materi Ajar siswa terdiri dari 32 halaman dengan muatan yaitu.

1) Bagian awal, terdiri dari; (a) tujuan pembelajaran yang hendak dicapai yang meliputi tujuan produk, tujuan proses, tujuan afektif, dan tujuan sosial; (b) fokus bab; dan (c) gambaran umum bahan kajian yang akan dipelajari pada masing-masing sub-pokok bahasan. 
2) Bagian inti, yang meliputi uraian tentang Aksi Interaksi (prinsip, konsep, fakta, dan contoh-contoh). Urutan isi materi diawali dengan topik pola-pola interaksi antara organisme yang menyusun ekosistem yang diikuti dengan pembahasan tentang pengalihan materi dan energi melalui rantai makanan dan jaring-jaring makanan. Urutan kedua adalah, materi tentang perubahan ekosistem hingga mencapai klimaks. Urutan yang terakhir adalah pembagian ekosistem yang ada di muka bumi berdasarkan komponen penyusunnya.

3) Bagian akhir Materi Ajar, berisikan rangkuman materi dan soal-soal latihan yang sifatnya penguatan, serta daftar pustaka.

Penelitian ini telah mengembangkan tiga Rencana Pelajaran yang disesuaikan dengan tingkat keluasan materi pokok bahasan Aksi Interaksi dan jumlah jam pelajaran untuk satu kali pertemuan pada sekolah tempat penelitian. Ketiga RP yang dihasilkan yaitu (1) RP-01 untuk pola-pola aksi interaksi antara komponen biotik dalam ekosistem, (2) RP-02 Siklus biogeokimia dan suksesi, dan (3) RP-03 macam-macam ekosistem yang ada di muka bumi. Rencana pelajaran yang dikembangkan memuat: (1) Tujuan Pembelajaran Umum, (2) Tujuan Pembelajaran Khusus, yang terdiri dari tujuan produk, tujuan proses, tujuan afektif, dan tujuan sosial, (3) Sumber pembelajaran, (4) Pengelolaan pembelajaran, yang meliputi model pembelajaran yang digunakan, metode belajar, dan alat peraga yang diperlukan dalam pembelajaran, dan (5) Urutan KBM sesuai sintaks pembelajaran kooperatif tipe jigsaw yang meliputi enam fase pembelajaran.

2. Lembar Kegiatan Siswa (LKS)
Lembar kegiatan siswa merupakan lembar panduan bagi siswa dalam mengerjakan tugas secara kelompok yang berorientasi pada model pembelajaran kooperatif tipe jigsaw. Lembar Kegiatan Siswa ini memuat uraian; (1) materi secara singkat, (2) tujuan pembelajaran, (3) petunjuk mengerjakan yang menuntut siswa bekerja secara kooperatif, dan (4) sejumlah pertanyaan yang dikelompokkan berdasarkan tugas kelompok ahli atau topiktopik kelompok ahli. Lembar Kegiatan Siswa yang berhasil dikembangkan dalam penelitian ini sebanyak empat, yang dibedakan menjadi dua bentuk, yaitu pertama, LKS-01a untuk kegiatan pengamatan pada komunitas sawah, dan yang kedua, LKS-01b, LKS-02, dan LKS-03 untuk diskusi secara kooperatif jigsaw di dalam kelas.

\section{Instrumen Evaluasi Hasil Belajar Siswa} Instrumen evaluasi hasil belajar siswa digunakan untuk menentukan kualitas hasil belajar siswa. Instrumen evaluasi hasil belajar berupa perangkat soal tes hasil belajar. Tes hasil belajar yang dikembangkan adalah tes hasil belajar produk dan proses. Tes hasil belajar produk mengacu pada TPK produk, sedangkan tes hasil belajar proses mengacu pada TPK proses. Tes hasil belajar ini sebagian disusun oleh peneliti dan sebagian diadopsi dari buku paket yang sudah ada. Sebelum digunakan untuk mengevaluasi hasil belajar siswa setelah berlangsungnya proses belajar mengajar dengan menerapkan perangkat pembelajaran yang telah dikembangkan oleh peneliti, instrumen tes hasil belajar telah direvisi melalui kegiatan Validasi Pakar dan Ujicoba I

\section{Hasil Analisis Reliabilitas Instrumen Pengamatan Berdasarkan Hasil Ujicoba I} Koefisien reliabilitas rata-rata instrumen observasi lebih besar dari $75 \%$. Sesuai 
dengan standard Borich (1994), instrumen tersebut termasuk dalam kategori instrumen baik. Dengan demikian, instrumen pengamatan yang telah diadposi oleh peneliti dari penelitian Pendi, S. (2002) dapat digunakan untuk menilai kualitas proses belajar mengajar pada Pembelajaran Nyata (Ujicoba II) penelitian ini.

\section{Hasil Observasi dan Analisis Implementasi Perangkat Pembelajaran Pada Pembelajaran Nyata (Ujicoba II). \\ 1. Kemampuan Guru Mitra dalam Mengelola Pembelajaran \\ Pada kegiatan Ujicoba II,} implementasi perangkat pembelajaran yang telah dikembangkan oleh peneliti, dilakukan oleh Guru Mitra. Guru Mitra sebelumnya telah diberi pemodelan dan dilatihkan pada Ujicoba I untuk menerapkan perangkat pembelajaran yang telah dikembangkan. Dalam kegiatan pengelolaan pembelajaran oleh Guru Mitra, termasuk dalam kategori baik. Ini artinya, Guru Mitra mampu mengikuti pengelolaan KBM yang berorientasi model pembelajaran kooperatif tipe jigsaw yang telah dimodelkan oleh peneliti. Dengan demikian, Guru Mitra dapat melaksanakan proses belajar mengajar yang berorientasi model pembelajaran kooperatif tipe jigsaw untuk pembelajaran pokok bahasan yang lain jika perangkat pembelajarannya tersedia. Hasil observasi menunjukkan, keseluruhan aspek dalam pengelolaan pembelajaran dengan model pembelajaran kooperatif tipe jigsaw, yang meliputi, Persiapan, Pelaksanaan, dan Pengelolaan waktu, adalah terlaksana dengan baik. Keterlaksanaan ini didukung oleh ketersediaan perangkat pembelajaran yang dikembangkan oleh peneliti, seperti Materi Ajar dan LKS. Kejelasan langkah kegiatan guru dan siswa pada RP dan LKS sangat menentukan keterlaksanaan PBM sesuai model pembelajaran yang diterapkan. Hasil analisis menunjukkan bahwa, pada umumnya kemampuan guru mitra dalam mengelola pembelajaran semakin meningkat (semakin membaik) pada RP1, RP2, dan RP3. Kemampuan guru tersebut semakin baik karena, pada setiap kali selesai penyampaian masing-masing $\mathrm{RP}$, peneliti melakukan diskusi dengan Guru Mitra untuk memberikan masukan untuk perbaikan pembelajaran pada tahap berikutnya.

\section{Aktivitas Guru dan Siswa dalam}

\section{Kegiatan Belajar Mengajar}

Selama pembelajaran dengan model pembelajaran kooperatif tipe jigsaw pada pokok bahasan Aksi Interaksi, aktivitas guru yang dominan adalah mengelola KBM sesuai kaidah pembelajaran kooperatif, yaitu $54.07 \%$ dan mendorong atau melatihkan keterampilan kooperatif pada siswa yaitu $30.00 \%$, sedangkan aktivitas guru dengan persentase rendah adalah menyampaikan TPK/Memotivasi siswa dan menyajikan informasi tentang materi pelajaran, yaitu masing-masing $\quad 6.67 \%$ dan $9.26 \%$. Tingginya persentase aktivitas guru dalam mendorong dan melatihkan keterampilan kooperatif siswa, membuktikan bahwa proses belajar mengajar yang dikelola oleh guru telah menunjukkan ciri pembelajaran kooperatif. Seperti yang dikemukakan oleh Carin (1993), bahwa salah satu ciri pembelajaran kooperatif adalah, selama proses belajar mengajar berlangsung, guru membantu melatihkan dan mengembangkan keterampilan-keterampilan interpersonal siswa dalam kelompok.

\section{Keterampilan Kooperatif Siswa}

Keterampilan kooperatif siswa diamati dengan menggunakan instrumen 03. Keterampilan kooperatif siswa yang muncul diamati setiap 3 menit pada waktu siswa melakukan keterampilan kooperatif. Pengamatan ditujukan kepada 10 orang yang terbagi dalam dua kelompok. Keterampilan kooperatif siswa dalam Ujicoba ini diamati selama siswa mengerjakan LKS pada kelompok ahli dan pada saat 
mempresentasikan hasil kerja kelompok pada kelompok asal. Selama pembelajaran yang berorientasi model pembelajaran kooperatif tipe jigsaw pada pokok bahasan Aksi Interaksi, keterampilan kooperatif yang dominan dilakukan siswa adalah mengambil giliran dan berbagi tugas yaitu $39.56 \%$, dan mendengarkan dengan aktif apa yang dikatakan teman atau guru, yaitu $30.00 \%$, sedangkan keterampilan kooperatif yang dilakukan siswa dengan persentase kecil adalah keterampilan bertanya, yaitu $8.44 \%$. Tingginya keterampilan kooperatif siswa dalam mengambil giliran dan berbagi tugas, karena pada setiap kali pembelajaran, guru selalu mendorong siswa untuk; bersedia menerima tugas, memberikan kepercayaan kepada teman untuk menyelesaikan tugas, bekerja sama dalam kelompok dan bersedia membantu teman dalam menyelesaikan tugas.

\section{Respon Siswa terhadap Perangkat dan Model Pembelajaran Kooperatif Tipe Jigsaw}

Selama pembelajaran yang

berorientasi model pembelajaran kooperatif tipe jigsaw pada pokok bahasan Aksi Interaksi umumnya siswa merasa senang. Seratus persen siswa merasa senang terhadap topik biologi yang dipelajari, LKS, Buku Siswa, penampilan guru, dan keterampilan kooperatif yang dilatihkan guru, dan 94\% siswa merasa senang dengan suasana kelas. Tingginya persentase ini ikut mendukung suksesnya pengelolaan pembelajaran yang dilakukan oleh guru selama PBM berlangsung, sehingga guru mitra dapat mengelola pembelajaran yang berorientasi model pembelajaran kooperatif tipe jigsaw dengan kategori baik. Tingginya persentase kesenangan siswa terhadap suasana kelas, terbukti dengan antusias siswa yang teramati oleh pengamat pada masing-masing RP dengan skor 3.72 atau kategori baik . Dari implementasi perangkat pembelajaran, umumnya siswa menganggap sebagai hal yang baru terutama pada Buku Siswa dan keterampilan kooperatif yang dilatihkan, $100 \%$ siswa menganggap sebagai hal yang baru. Tingginya persentase siswa yang merasa senang dan menganggap baru dengan perangkat dan model pembelajaran kooperatif tipe jigsaw tersebut, berimplikasi terhadap minat siswa untuk mengikuti KBM berikutnya seperti yang pernah mereka ikuti. Hal ini juga diperkuat dengan hasil respon siswa, yaitu $100 \%$ siswa berminat untuk mengikuti KBM berikutnya seperti yang telah diikuti.

\section{Kesan guru terhadap Perangkat dan Model Pembelajaran Kooperatif Tipe Jigsaw}

Secara umum Guru Mitra menganggap perangkat pembelajaran yang telah dikembangkan peneliti cukup membantu dalam proses belajar mengajar pokok bahasan Aksi Interaksi. Salah satu manfaat yang bisa diperoleh dari penerapan perangkat dan model pembelajaran kooperatif tipe jigsaw menurut Guru Mitra adalah, siswa lebih berani menyampaikan hasil yang diperolehnya kepada siswa lain. Hasil yang dimaksud adalah, pengetahuan yang diperoleh siswa melalui LKS pada saat diskusi pada kelompok ahli.

\section{Hasil Belajar Produk}

Pembelajaran yang menerapkan perangkat dan model pembelajaran kooperatif tipe jigsaw pada pokok bahasan Aksi Interaksi oleh Guru Mitra pada MAN 2 Madiun menyebabkan $88.64 \%$ siswa telah tuntas belajarnya untuk tujuan produk, karena persentase siswa yang telah tuntas belajarnya di atas standar ketuntasan yang ditetapkan dalam Kurikulum 1994, yaitu $85 \%$. Oleh karena itu, pembelajaran dengan menggunakan model pembelajaran kooperatif tipe jigsaw pada pokok bahasan Aksi Interaksi dapat meningkatkan kualitas hasil belajar siswa, karena dapat menuntaskan TPK produk dalam pembelajaran. 
Terdapat tiga orang $(11.36 \%)$ siswa yang tidak tuntas belajarnya untuk THB produk. Berdasarkan hasil wawancara dengan siswa yang tidak tuntas belajarnya tersebut, siswa menyatakan bahwa mereka terkecoh dengan butir pilihan, karena butir pilihan dianggap mirip atau hampir sama. Sebagian siswa menyatakan tidak ingat dengan pengertian istilah pada pembagian daerah atau komunitas pada ekosistem danau dan ekosistem air laut, seperti istilah profundal, limnetik, dan bentik.

\section{Tes Hasil Belajar Proses}

Tes hasil belajar proses dengan jumlah soal enam butir, semuanya adalah berbentuk uraian yang diberikan dua kali, yaitu pada ujiawal (U1) dan ujiakhir (U2), yang diikuti oleh 26 orang siswa. Hasil analisis membuktikan bahwa, terdapat dua orang siswa yang tidak tuntas belajarnya untuk TPK proses, yaitu siswa dengan nomor urut 20 dan 22. Berdasarkan wawancara dengan siswa yang bersangkutan, diperoleh keterangan bahwa siswa salah persepsi terhadap butir soal nomor 1, 3 dan butir soal nomor 5. Walaupun terdapat dua orang siswa yang tidak tuntas belajarnya terhadap TPK proses, tetapi secara keseluruhan siswa telah tuntas belajarnya untuk TPK proses, karena $92.30 \%$ siswa yang telah mengikuti KBM telah tuntas belajarnya. Dengan demikian, pembelajaran yang berorientasi pada model pembelajaran kooperatif tipe jigsaw pada pokok bahasan Aksi Interaksi dapat menuntaskan belajar siswa.

Dari kedua hasil belajar produk dan proses di atas, diperoleh gambaran bahwa TPK yang disusun oleh peneliti telah tuntas dikuasai oleh siswa, dan siswa tuntas belajarnya, baik secara individual maupun secara klasikal. Ini berarti bahwa, pembelajaran dengan menerapkan perangkat pembelajaran dengan model pembelajaran kooperatif tipe jigsaw pada pokok bahasan Aksi Interaksi yang dikembangkan peneliti, mempunyai kualitas proses dan kualitas hasil belajar yang baik. Hasil tersebut sejalan dengan yang dikemukaan oleh Slavin (1994), bahwa pembelajaran kooperatif dapat memperbaiki prestasi akademik siswa dan membantu siswa memahami konsep-konsep yang sulit.

\section{SIMPULAN}

1. Perangkat pembelajaran yang berhasil dikembangkan dan mendukung kualitas proses dan kualitas hasil belajar mengajar pokok bahasan Aksi Interaksi pada Madrasah Aliyah, pada penelitian ini terdiri dari; Rencana Pembelajaran, Buku Siswa, LKS, Instrumen Evaluasi Hasil Belajar Siswa Pokok Bahasan Aksi Interkasi, dan Pedoman Pelaksanaan Pembelajaran dengan model pembelajaran kooperatif tipe jigsaw.

2. Guru Mitra mampu melakukan keseluruhan aspek dalam sintaks pembelajaran kooperatif tipe jigsaw seperti yang telah dicontohkan oleh Guru Model pada saat Ujicoba I, dengan kategori baik.

3. Aktivitas guru didominasi dengan kegiatan mengelola KBM sesuai dengan kaidah pembelajaran kooperatif, dan mendorong atau melatihkan siswa keterampilan kooperatif.

4. Akitivitas siswa didominasi dengan kegiatan membaca buku siswa, LKS, dan menulis yang relevan, dan aktivitas berlatih melakukan keterampilan kooperatif. Aktivitas berlatih melakukan keterampilan kooperatif meningkat seiring dengan tingginya persentase aktivitas guru dalam melatihkan keterampilan kooperatif pada siswa.

5. Keterampilan kooperatif yang dominan dilakukan oleh siswa adalah keterampilan mengambil giliran dan berbagi tugas dalam kelompok untuk menyelesaikan tugas-tugas kelompok.

6. Pada umumnya siswa menyatakan senang dan baru terhadap perangkat 
pembelajaran dan model pembelajaran kooperatif tipe jigsaw yang telah dikembangkan oleh peneliti, sehingga siswa berminat untuk mengikuti KBM berikutnya seperti yang telah mereka ikuti.

7. Guru Mitra menganggap perangkat pembelajaran yang telah dikembangkan peneliti cukup membantu dan sangat bermanfaat dalam proses belajar mengajar pokok bahasan Aksi Interaksi.

8. Proses belajar mengajar yang menerapkan perangkat pembelajaran dengan model pembelajaran kooperatif tipe jigsaw pada pokok bahasan Aksi Interaksi dapat meningkatkan proporsi jawaban benar siswa. Untuk THB produk sebesar 0.46 , dan THB proses meningkat sebesar 0.78 , sehingga TPK produk dan proses yang dikembangkan oleh peneliti telah tuntas dikuasai oleh siswa, baik secara individual maupun secara klasikal. Hal ini menunjukkan bahwa secara umum siswa telah memahami konsep Aksi Interaksi melalui pengajaran dengan menerapkan perangkat dan model pembelajaran kooperatif tipe jigsaw.

\section{SARAN}

Beberapa saran dari hasil penelitian yang telah dilakukan ini adalah:

1. Untuk mencapai kualitas proses belajar mengajar dan kualitas hasil belajar yang baik dalam pembelajaran dengan model pembelajaran kooperatif tipe jigsaw diperlukan persiapan perangkat pembelajaran yang cukup memadai, misalnya Rencana Pembelajaran, Buku Siswa dan LKS yang harus dimiliki oleh setiap siswa, dan instrumen penilaian baik untuk penilaian formatif (kuis) maupuan penilaian sumatif.

2. Bagi pihak lain yang ingin menerapkan perangkat pembelajaran yang telah dikembangkan oleh peneliti ini, sedapat mungkin terlebih dahulu dianalisis kembali untuk disesuaikan penerapannya, terutama dalam hal alokasi waktu, fasilitas pendukung termasuk media pembelajaran, dan karakteristik siswa yang ada pada sekolah tempat perangkat ini akan diterapkan.

3. Dalam mengembangkan perangkat pembelajaran, terutama buku siswa, LKS, dan THB hendaknya menggunakan bahasa atau istilah yang mudah dimengerti oleh siswa atau bahasa yang tidak menimbulkan penafsiran ganda oleh siswa, dan menyajikan contoh-contoh yang memadai yang sudah dikenali oleh siswa dari lingkungan hidupnya.

\section{DAFTAR PUSTAKA}

Abruscato, J. 1999. Teaching Children Science: A Discovery Approach. New York: Allyn and Bacon.

Arends, R. I. 1997. Classroom Instruction and Management. New York: McGraw Hill Companies. 2001. Learning to Teach. New York: McGraw Hill Companies.

Arikunto, S. 1991. Dasar-dasar Evaluasi Pendidikan. Jakarta: Bumi Aksara.

Azizy, A. 2002. "Memberdayakan pesantren dan madrasah". Editor; Ismail, S.M., Nurul Huda, \& Abdul Kholik. Dinamika Pesantren dan Madrasah. Yogyakarta: Pustaka Pelajar.

Borich, G.D. 1994. Observation Skill for Effective Teaching. New York: Macmillan Publishing Company.

Budiningarti, H. 1998. "Pengembangan Strategi Pembelajaran Kooperatif Tipe Jigsaw Pada Pengajaran Fisika di SMU'. Tesis Magister Pendidikan, PPs IKIP Surabaya. 
Carin, A. 1993. Teaching Modern Science. New York: Macmillan Publishing Company.

Depdikbud. 1993. Garis-garis Besar Program Pengajaran Sekolah Menengah Umum. Jakarta: Departemen Pendidikan dan Kebudayaan Republik Indonesia.

1995. Kurikulum Sekolah Menengah Umum: Petunjuk Teknis Mata Pelajaran Biologi. Jakarta: Departemen Pendidikan dan Kebudayaan Republik Indonesia.

Gronlund, N.E. 1995. How to Write and Use Instructional Objectives Fifth Edition. Englewood Cliffs, New Jersey: Prentice Hall Inc.

Gronlund, N.E. 1982. Constructing Achievement Test. Englewood Cliffs, New Jersey: Prentice Hall Inc.

Howe, A.C. \& Jones, L. 1993. Engaging Children in Science. New York: Macmilan Publishing Company.

Ibarat, T., Melani, K., \& Bagod, S., 2000. Prestasi Biologi I. Bandung: Ganeca Exact.

Ibrahim, M., Fida R., Nur, M. dan Ismono. 2000. Pembelajaran Kooperatif. Surabaya: Unesa Press.

Karim, 2000. Kurikulum Berbasis Kompetensi. Jakarta: Pusat Kurikulum Balitbang Diknas.

Karmana, O., 2002. Biologi untuk SMU Kelas I. Berdasarkan Suplemen GBPP 1999, Pembelajaran Mengarah pada Kurikulum Berbasis Kompetensi. Bandung: Grafindo Media Pratama.

Kemp, J.E., G.R. Morisson, \& Steven M. R. 1994. Designing Effective Instruction.
New York: Macmillan College Publishing Company.

Lederer, R.J. (1985) Ecology and Field Biology. California: The Benjamin/Cummings Publishing Company, Inc.

Lie, A., 1994. Jigsaw: A Cooperative Learning Method for the Reading Class. Waco, Texas: Phi Delta Kappa Society.

Lungdren, L. 1994. Cooperative Learning in The Science Classroom. New York: McGraw Hill Companies.

Madrasah Aliyah Putri NW Narmada. 2002. Laporan Tahunan Lulusan MA Putri $N W$ Narmada. Lombok Barat: Ponpes Nurul Haramain Putri NW.

Magfurin, A. 2002. "Pesantren: Model pendidikan masa depan". Editor; Ismail, S.M., Nurul Huda, \& Abdul Kholik. Dinamika Pesantren dan Madrasah. Yogyakarta: Pustaka Pelajar.

Muhtarom. 2002. "Urgensi pesantren dalam pembentukan kepribadian muslim". Editor; Ismail, S.M., Nurul Huda, \& Abdul Kholik. Dinamika Pesantren dan Madrasah. Yogyakarta: Pustaka Pelajar.

Nur, M. 1999a. "Perangkat Pembelajaran Sains Mampu Memenuhi Kebutuhan Individu". Makalah Disampaikan pada Presentasi Hasil Program Remedial di Ditdikmenum Jakarta, Universitas Negeri Surabaya.

Nur, M. 1999b. Developing of Science Instructional Model Using Process Approach to Increase Student Reasoning and Thinking Ability, Suplement 1.0. Project URGE Batch 
III 1996/1997. Directorate General of Higher Education, Ministry of Education and Culture.

Pendi, S. 2002. "Pembelajaran Fisika Dasar II Pokok Bahasan Arus Listrik dan Rangkaian Listrik Arus Searah dengan Menggunakan Model Pembelajaran Kooperatif Tipe Jigsaw". Tesis Magister Pendidikan, PPs Universitas Negeri Surabaya.

Pratiwi, D.A., Sri, M., Srikini, Suharno, \& Bambang, S. 2000. Buku Penuntun Biologi Untuk SMU Kelas I. Jakarta: Erlangga.

Setyanigsih, S. 1999. "Pembelajaran Kooperatif Tipe Jigsaw Untuk Meningkatkan Kualitas Proses dan Hasil PBM Biologi Kelas IIIB di SLTP GIKI 2 Surabaya". Tugas Akhir, FPMIPA IKIP Surabaya.

Slavin. 1995. Cooperative Learning Theory. Second Edition. Massachusetts: Allyn and Bacon Publisher.

Slavin. 1994. Educational Psychology, Theory and Practice. Needham Heights: Allyn \& Bacon.

Suparno, P. 1997. Filsafat Konstruktivis dalam Pendidikan. Jakarta: Penerbit Kanisius.

Thompson, M., McLaughlin, C.W., \& Smith, R.G. 1995. Merril Physical Science Teacher. Wraparound Edition. New York: Glencoe McGraw-Hill.

Tilaar, H. 1997. "Paradigma Baru Pendidikan Nasional". Editor: Ali Saukah. Jurnal Ilmu Pendidikan, Jilid 7 Desember 1997. Jakarta: LPTK \& ISPI.
Tuckman, B.W. 1978. Conducting Educational Research. Second Edition. New York: Harcourt Brace Jovanovich.

Widada, W. 1999. "Pengembangan Perangkat Pembelajaran Matematika SMU Yang Berorientasi Model Pembelajaran Kooperatif Tipe Jigsaw". Tesis Magister. Pendidikan, PPs IKIP Surabaya.

Woolfolk, A. 1993. Educational Psychology. Fifth Edition. Needham Height: Allyn and Bacon Publishers.

Yusuf, 2003. "Kualitas Proses dan Hasil Belajar Biologi Pokok Bahasan Aksi Interaksi Melalui Pengajaran dengan Model Pembelajaran Kooperatif Tipe Jigsaw pada Madrasah Aliyah Kelas I Ponpes Nurul Haramain Putri Narmada Lombok Barat NTB”. Makalah Komprehensif Magister Pendidikan, PPs Universitas Negeri Surabaya. 